\title{
COASTAL STUDIES AT HEARD ISLAND 1992/93: CHANGES IN SEA SURFACE TEMPERATURE AND COASTAL LANDFORMS
}

\author{
by Ken Green
}

\author{
(with one table and five text-figures)
}

\begin{abstract}
Green, K., 2000 (30:vi): Coastal studies at Heard Island 1992/93: Changes in sea surface temperature and coastal landforms. In Banks, M.R. \& Brown, M.J. (Eds): HEARD ISLAND PAPERS. Pap. Proc. R. Soc. Tasm. 133(2): 27-32. ISSN 0080-4703. Australian Institute of Alpine Studies, P0 Box 2228, Jindabyne, NSW, Australia 2627.
\end{abstract}

Sea temperature was measured weekly at Spit Bay, Heard Island, from April 1992 to March 1993. Temperatures were generally higher than those recorded in 1949 (at Atlas Cove), but these sites are not strictly comparable. Sea temperatures around Heard Island were stable from the 1920 s to the 1940 s, with a general increase in sea surface temperatures in the region being a recent phenomenon accompanied by widespread glacial retreat and the accelerated erosion of coastal features since the early 1950 s. There is an area of active erosion by both water and wind in an arc from Winston Lagoon on the southeastern coast through to the northeastern coast at Compton Lagoon. This is most likely an effect of the loss of glaciers allowing strong erosive water movement along the coast. Movements of this dynamic coastline have important implications for long-term monitoring studies and for the management of the island.

Key Words: global warming, glaciers, erosion, Heard Island.

\section{INTRODUCTION}

Those researchers looking for evidence of, or a visible result of climate change on land look preferentially to glaciers. However, the retreat or mass diminution of glaciers also has a flow-on effect, the retreat of tidewater glaciers in particular altering coastal dynamics. Changes in coastal morphology at Heard Island $\left(53^{\circ} 06^{\prime} \mathrm{S}, 73^{\circ} 32^{\prime} \mathrm{E}\right)$ have always been of greatest interest to those whose mode of transport on the island has been foot. Ledingham (1987), for example, included a map and accompanying text describing access by foot around the island in 1986/87. Most observed changes to the coast since human occupation of Heard Island have glacial retreat as their proximate cause, with climate warming as the ultimate cause (Allison \& Keage 1986).

The impact of glacial retreat on the coastal morphology of the northwestern end of Heard Island has been negligible. Jacka Glacier, for example, prevented travel to Red Island from Atlas Cove in the early ANARE days (1947-54), but its retreat, while making travel possible by foot, has not altered the coastline of the Laurens Peninsula (fig. 1). The beach in front of the Vahsel Glacier was considered uncrossable in 1985, with ice falls and waves to the snout (Burton \& Williams 1985), and was reported in the 1986/ 87 expedition to be passable at low tide but dangerous, due to large ice falls (Ledingham 1987). The $1987 / 88$ expedition made several crossings at low tide (E.J. Woehler, pers. comm.). Such differences in opinion may be due more to the state of the tides than large-scale changes in the beach. A cursory examination of the coast of the northwestern end of Heard Island over a period of a month in early 1992 showed no great differences from the situation documented in $1987 / 88$ by Kirkwood (1989a).

This paper is mainly concerned with the area of active crosion along the coastline of Heard Island in an arc from Winston Lagoon on the southeastern coast around to the northeastern coast at Compton Lagoon. Changes to the glaciers themselves have been dealt with by Allison $\&$ Keage (1986). Loss of mass in a glacier will not have an immediate impact upon rates of coastal erosion; hence, glacial retreat will only be covered insofar as it affects the coastal morphology. Therefore, this paper is concerned with evidence of warming in the Heard Island area and the impact this is having on the coastal morphology.

\section{METHODS}

Sea temperature was measured weekly at Spit Bay camp from April 1992 to March 1993. Water was collected in a plastic bucket from the sea within $1 \mathrm{~m}$ of the cobble beach. Temperature was measured in the morning to avoid any confounding effect of diurnal variation. The temperature was recorded to the nearest $0.1^{\circ} \mathrm{C}$ with a standard meteorological thermometer (Dobbie $-20^{\circ} \mathrm{C}$ to $+60^{\circ} \mathrm{C}$ ). Sea temperatures taken from the RSV Aurora Australis at Spit Bay and in Atlas Cove on 23 January 1992 were compared. Temperatures taken from the shore of Spit Bay were compared with those taken from the MV Icebird on 11 and 12 March 1993, whilst it was anchored off Spit Bay.

Meteorological observations began at Spit Bay on 1 March with temporary housing for the instruments. The screen and raingauge were set up on $7 \mathrm{March}$ and instruments zeroed at 0000 GMT the following morning, so official observations began on 9 March. Standard meteorological observations were made at 0000 GMT which was 0500 local Heard Island time.

Observations of coastal changes were obtained from photographs, previous expedition reports and direct observations in 1990 and $1992 / 93$. Surface water was collected from Stephenson Lagoon and from the sea off Spit Bay in March 1993. Density values of these samples were determined with an Anton Paar DMA 55 density meter, with salinity values calculated after Whitfield \& Jagner (1981). 


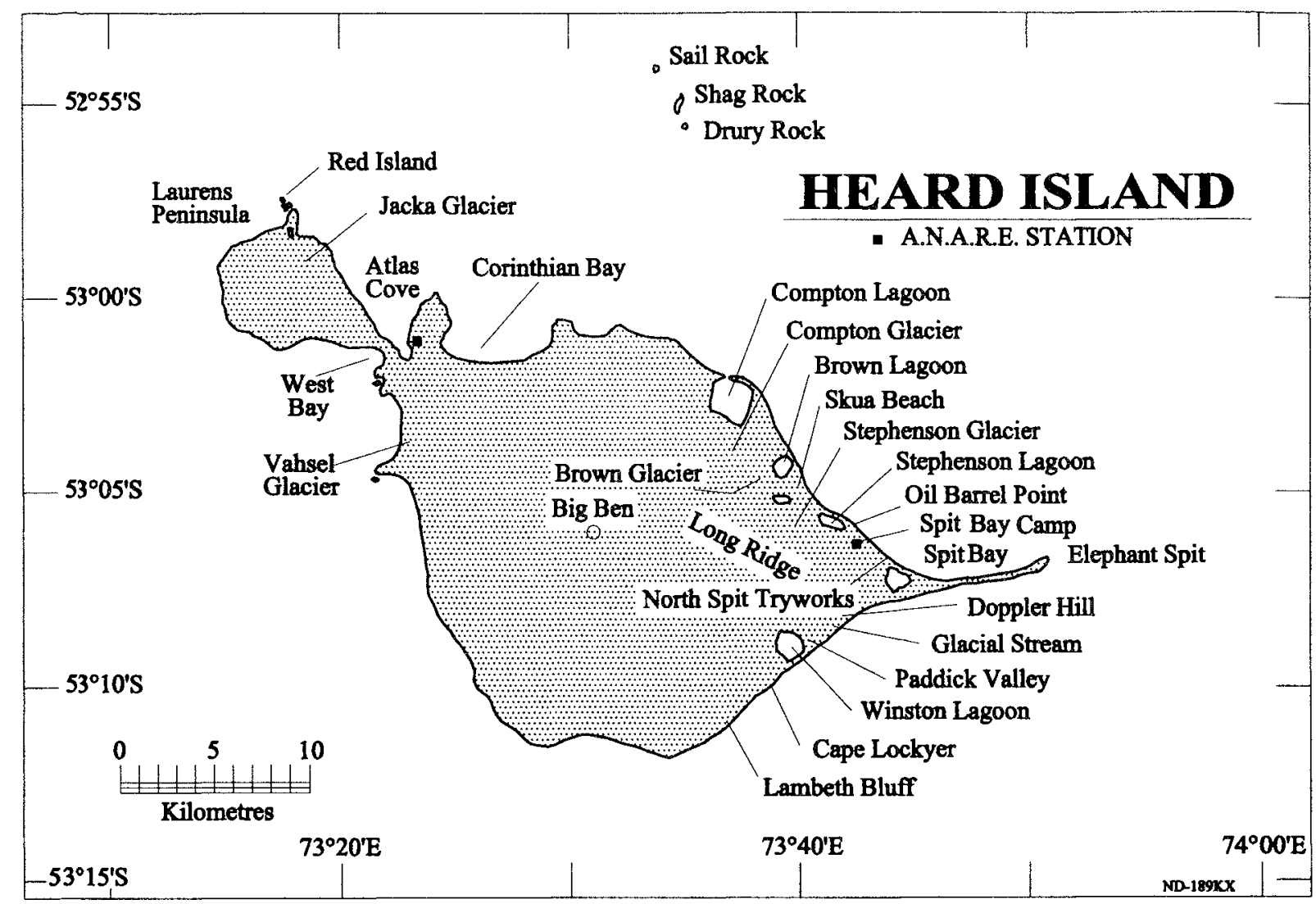

FIG.1 - Heard Island, showing places referred to in the text.

\section{RESULTS AND DISCUSSION}

\section{Sea Surface Temperature}

The Spit Bay site was not strictly comparable to that used by Ealey \& Chittleborough (1956) in 1949 (their station II), which was about $400 \mathrm{~m}$ offshore over $9 \mathrm{~m}$ of water in the comparative calm of Atlas Cove. Temperatures recorded at Spit Bay in 1992/93 were similar to those given for Antarctic surface waters at the Antarctic Convergence in summer and winter respectively (Deacon 1933). By contrast, Ealey $8 x$ Chittleborough (1956) found that air temperatures lowered the water temperature in 1949 , with the effect being greater closer to shore. The relationship with conditions on shore, which are dependent upon the surrounding Antarctic water mass (Allison \& Keage 1986), and how this relationship, in turn, affects the temperature of nearshore waters is difficult to unravel. However, the $3.4^{\circ} \mathrm{C}$ recorded from the shore of Spit Bay on 8 March 1993 was similar to the $3.2^{\circ}-3.4^{\circ} \mathrm{C}$ recorded from the MV Icebird off Spit Bay on 11 and 12 March 1993. Sea temperature at Spit Bay dropped by about $2^{\circ} \mathrm{C}$ from April to late June 1992 and then fluctuated around $1^{\circ} \mathrm{C}$ throughout the winter (reaching a low of $0.4^{\circ} \mathrm{C}$ on 19 October 1992) before rising from late November (fig. 2). Surface water temperatures recorded in Atlas Cove were generally lower in 1949 and fell to below zero, with sea ice recorded on two occasions (Ealey \& Chittleborough 1956). The photograph in Ealey \& Chittleborough (1956) showed that the ice was not just a skin on the water but quite robust pancake ice. Minimum temperatures at Atlas Cove in 1949 for 8/9 July and 2/3 August (the days before and during ice formation) were $-8.9 \%-8.9^{\circ} \mathrm{C}$ and $-10.6 \%$ $7.8^{\circ} \mathrm{C}$ respectively (Bureau of Meteorology 1953 ). Both the average maximum and the average minimum air temperatures over the period covered by Ealey \& Chittleborough (1956) were lower than at Spit Bay in 1992/93. Air temperatures at Spit Bay in 1992 fell to a minimum of $-7.2^{\circ} \mathrm{C}$, with Stephenson Lagoon freezing to a depth of at least $0.5 \mathrm{~m}$ through the winter. However, unlike the waters of Atlas Cove in 1949, the calm saline waters of Compton Lagoon did not freeze in winter 1992. Temperatures recorded from the RSV Aurora Australis on 23 January 1992 were similar at Spit Bay at $1100 \mathrm{~h}\left(2.6^{\circ} \mathrm{C}\right)$ and at Atlas Cove at $1230 \mathrm{~h}$ $\left(3.0^{\circ} \mathrm{C}\right)$. These factors together would indicate that, although the two sites are not strictly comparable, the higher sea temperatures recorded in 1992 compared with those in 1949 may well be indicative of a general warming of the

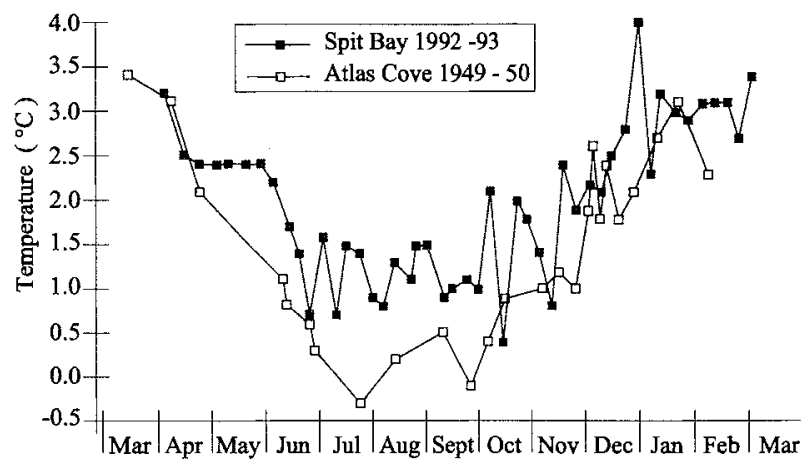

FIG. 2 - Sea surface temperature recorded at Spit Bay Camp in 1992/93 and at Atlas Cove in 1949/50. 
TABLE 1

Monthly summary of meteorological data for Atlas Cove 1949-54 and Spit Bay 1992-93

\begin{tabular}{|c|c|c|c|c|c|c|c|c|}
\hline Month & $\begin{array}{c}\text { Mean } \\
\text { maximum } \\
1992 / 93\end{array}$ & $\begin{array}{c}\text { Mean } \\
\text { maximum } \\
1949 / 50\end{array}$ & $\begin{array}{l}\text { Range of } \\
\text { mean } \\
\text { maxima } \\
1949-54\end{array}$ & $\begin{array}{c}\text { Mean } \\
\text { minimum } \\
1992 / 93\end{array}$ & $\begin{array}{c}\text { Mean } \\
\text { minimum } \\
1949 / 50\end{array}$ & $\begin{array}{l}\text { Range of } \\
\text { mean } \\
\text { minima } \\
1949-54\end{array}$ & $\begin{array}{c}\text { Lowest } \\
\text { minimum } \\
1992 / 93\end{array}$ & $\begin{array}{l}\text { Lowest } \\
\text { minimum } \\
1949-50\end{array}$ \\
\hline Jan and Feb* & 5.2 & & & 1.3 & & & -0.5 & \\
\hline March & 6.5 & 5.3 & 3.7 to 5.8 & 0.8 & 1.2 & 0.6 to 2.0 & -1.5 & -1.9 \\
\hline April & 7.0 & 4.9 & 2.9 to 5.4 & 1.3 & 0.6 & 0.6 to 1.3 & -0.5 & -3.3 \\
\hline May & 4.3 & 3.1 & 2.6 to 4.4 & -0.4 & -0.8 & -0.8 to 0.9 & -2.8 & -5.5 \\
\hline June & 4.4 & 0.7 & 0.6 to 2.7 & -1.6 & -3.8 & -3.8 to -0.3 & -4.5 & -8.5 \\
\hline July & 2.0 & -0.5 & -0.5 to 2.6 & -2.3 & -4.8 & -4.8 to -0.8 & -5.5 & -9.1 \\
\hline August & 2.0 & 0.4 & 0.4 to 2.7 & -2.7 & -3.8 & -3.8 to -1.0 & -6.5 & -10.6 \\
\hline September & 4.9 & 0.1 & 0.1 to 1.8 & -2.5 & -4.6 & -4.6 to -2.3 & -7.2 & -8.8 \\
\hline October & 4.0 & 1.2 & 0.9 to 2.2 & -2.4 & -2.5 & -2.5 to -1.1 & -6.0 & -7.3 \\
\hline November & 6.8 & 1.4 & 1.4 to 3.3 & -0.1 & -1.7 & -1.7 to 0.0 & -2.8 & -3.5 \\
\hline December & $6.7(5.1)$ & 3.6 & 3.6 to 4.4 & $1.1(1.4)$ & 0.3 & 0.3 to 0.9 & -0.8 & -1.8 \\
\hline January & 6.6 & 5.0 & 4.7 to 5.5 & 1.3 & 1.2 & 1.1 to 1.9 & -0.5 & 0.1 \\
\hline February & 9.8 & 4.7 & 4.6 to 6.0 & 1.7 & 1.3 & 1.3 to 2.4 & -1.5 & -0.8 \\
\hline $\operatorname{March}^{\dagger}$ & 6.9 & & & 0.6 & & & 0.3 & \\
\hline March to Feb & 5.4 & & & -0.5 & & & -7.2 & \\
\hline
\end{tabular}

* 23 days only at Atlas Cove

† Records taken for the first ten days of March 1993.

surface waters around Heard Island. The possibility that the temperature rise is due to volcanic activity is not borne out by the rise in temperature and retreat of glaciers at Iles Kerguelen, despite the lack of volcanic activity there (Allison \& Keage 1986), and an explanation must be sought elsewhere.

The five-year mean zonally averaged data of Paltridge $\&$ Woodruff (1981) showed sea surface temperatures in the Heard Island region roughly constant from 1880 to the late 1920 s but then increasing steadily to 1977 . Temperatures recorded at Atlas Cove in November $1949\left(1.0^{\circ}-\right.$ $1.2^{\circ} \mathrm{C}$ ) did not differ much from the $0.9^{\circ}$ to $1.2^{\circ} \mathrm{C}$ taken in Corinthian Bay in November 1929 (Howard \& Sverdrup 1940). There were no obvious changes in the glaciers between the 1874 Challenger expedition and the 1929 BANZAR expedition, with only minor recession to 1955 (Budd \& Stephenson 1970). These data suggest that what temperature rises there have been have mainly occurred since the 1950s. The accompanying glacial recession (in horizontal extent and/or depth), occurring between 1947 and 1980 , mainly took place since 1970 , in response to an increase in atmospheric temperatures since the mid $1960 \mathrm{~s}$ (Allison \& Keage 1986). The significance and uniformity of trends of higher temperature in the South Polar and Southern Ocean regions is increasing as more data are collected (Jacka \& Budd 1991), and so the effects of this warming might be expected to be observed at Heard Island for some time.

\section{Meteorological Observations}

A full summary of meteorological data collected by the 1992 wintering ANARE expedition is included in the expedition report (Green 1993a). Here, I concentrate on comparisons with the conditions during the sea surface temperature study of Ealey \& Chittleborough (1956) (table 1). The mean maximum temperature of $5.4^{\circ} \mathrm{C}$ for the months for which data are complete (March 1992 to February 1993) was $1.6^{\circ} \mathrm{C}$ higher than for 1949 , but the mean minimum $\left(-0.5^{\circ} \mathrm{C}\right)$ was close to the average for the six-year period (1949-54). The lowest minimum $\left(-7.2^{\circ} \mathrm{C}\right)$ was also close to the average of the lowest minima at Atlas Cove for the sixyear period (1949-54). The highest maximum, however, the $21.6^{\circ} \mathrm{C}$ recorded in April 1993, was well above the highest for any year in the 1949-54 period, and on nine days spread across four months (April, June, September and February) the maximum recorded was higher than for the six-year period (1949-54). These temperatures all occurred on days when fohn winds blew and would have inflated the average maxima but, because temperatures were only taken once a day, unlike at Atlas Cove (where permanent observers took three-hourly recordings), average temperature figures cannot be obtained from our data. The lack of average temperature data, however, is compensated for by other studies. Jacka et al. (1984), for example, examined surface temperature data for islands in the Southern Ocean and reported a general warming over the past 40 years. Additionally, using data collected by an Automatic Weather Station at Atlas Cove (April 1980 to February 1983), Allison 8 Keage (1986) estimated a temperature increase at Heard Island similar to the $1.5^{\circ} \mathrm{C}$ recorded at Iles Kerguelen after 1964. The rate of warming at Heard Island is consistent with that expected from predictions of global warming due to the enhanced greenhouse effect (Jacka \& Budd 1991).

\section{Changes in Coastal Morphology $1987 / 88$ to $1992 / 93$}

\section{Lagoons in winter}

There are four major pro-glacial lakes at the eastern end of Heard Island which can form a barrier to coastal movement on foot in summer but, except for Compton Lagoon, provided a rapid means of transport in winter 1992. Winston Lagoon had ice that would support a skier up to 100-200 m from the shore (fig. 3). Although the extent of the ice did not 


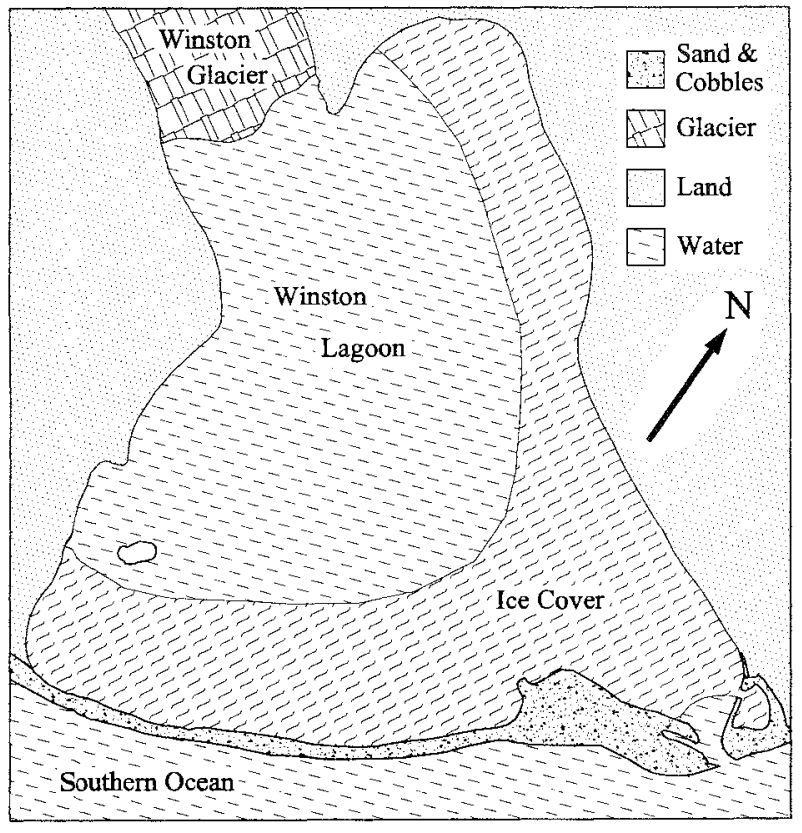

FIG. 3 - Extent of ice on Winston Lagoon, 23 July 1992. Length of $N$ arrow represents $0.5 \mathrm{~km}$.

increase markedly from that mapped, it later expanded in the southwestern corner of the lagoon, allowing access to the small island located there. The pro-glacial lake forming behind Glacial Stream (see below) could be crossed on ice for much of the winter, but increased salinity made the ice softer and less safe for travel as winter progressed. The freshwater Stephenson Lagoon was frozen through winter 1992, except at the outlet and at the foot of the ice cliffs of Stephenson Glacier. Stephenson Lagoon had the deepest measured ice of the pro-glacial lakes. Brown Lagoon froze from the sea to the snout of Brown Glacier in 1992 with solid ice throughout, but ice thickness was not measured.

\section{Southeastern coast}

There was continued erosion, both by water and wind, of the southeastern coast of Heard Island through 1992. There is a large input of sediment from high-erosion areas such as that from Cape Lockyer to Lambeth Bluff. Erosion on the southeastern coast was most noticeable at the westernmost moraine of Paddick Valley (as also reported by Kirkwood $1989 \mathrm{~b}$ ) and along the moraine and beach between Paddick Valley and Doppler Hill. A number of agents were responsible, including wave action, wind, erosion through snow movement or water runoff. Allison \& Keage (1986) commented on the widening of beaches east of Cape Lockyer. This widening was sporadic, and at one stage, in 1992/93, it was possible to walk around Cape Lockyer on a temporary beach. Additionally, the beach below Doppler Hill was extended outwards during the southern elephant seal (Mirounga leonina) breeding season of 1992/93. The southeastern coast is the major source of material for aeolian deposits on the Spit. This deposition is particularly evident during the southern elephant seal breeding season, when harems act in a similar fashion to snow fences, trapping enormous quantities of sand, so that the harem may rise up to a metre above the surrounding beach.

\section{Glacial Stream}

There have been a number of changes to both Glacial Stream and the pro-glacial lake formed behind it. The outlet has

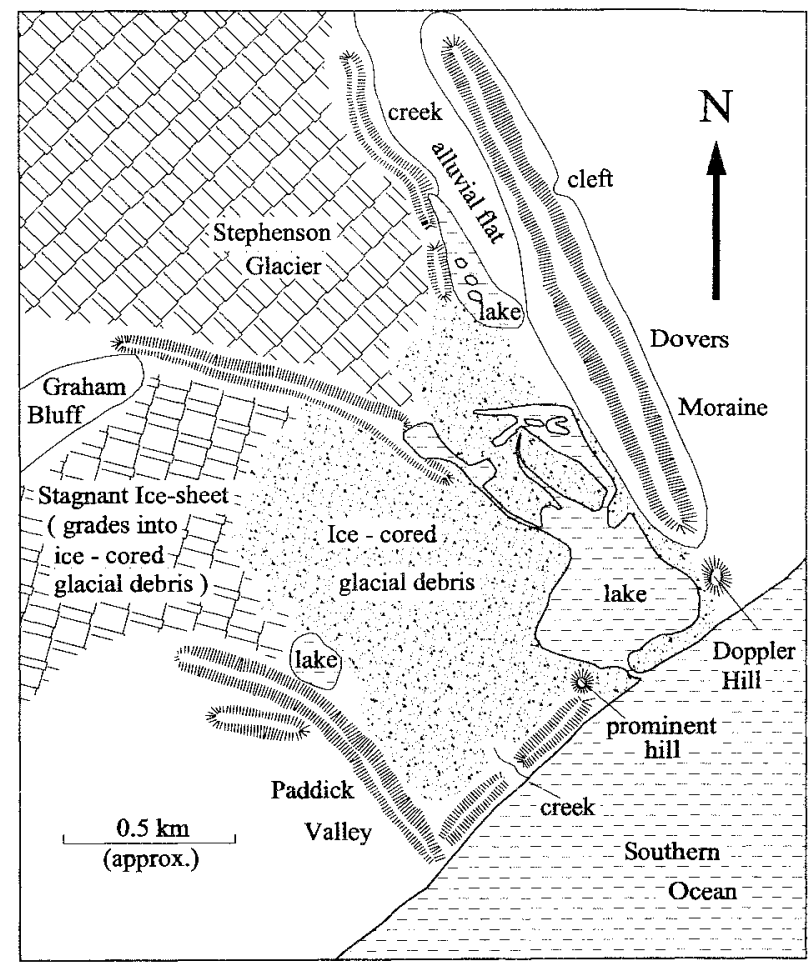

FIG. 4-Extent of pro-glacial lake feeding Glacial Stream, 1992.

been considerably widened since 1987 (much of this widening occurred before the ANARE expedition of 1990), and the pro-glacial lake was larger in 1992/93 than in 1987/88 (fig. 4). The stream and pro-glacial lake became tidal in 1992, turning the water brackish when the outlet was deepened sufficiently to allow the high tide to return against the flow of freshwater. Intense erosion and longshore drift along the southeastern coast with deposition in the Glacial Stream outlet in 1992/93 at times re-formed the sandbar and prevented the influx of seawater.

\section{Elephant Spit to Spit Bay Camp}

Elephant Spit was complete from early in 1992 through to September, when it was again broached. The resulting island was separated from the Spit by shallows as late as February 1993 when a crossing could be maddû Observations from Long Ridge in 1992 suggested that the spit had curved to the north since 1990 .

The coast from Elephant Spit to Spit Bay Camp is subject to intense erosion, although the extent can only be determined at a few places. Kirkwood (1989a) reported the North Spit tryworks to be about $30 \mathrm{~m}$ inland in $1987 / 88$. Green (1990) reported "extensive beach erosion" at the tryworks, and photographs taken at that time show the tryworks to be about $10 \mathrm{~m}$ inland of a $3 \mathrm{~m}$ high sea-cut cliff. During 1992, parts of the cliff fell away, and the tryworks was only $3 \mathrm{~m}$ from the sea-cut cliff by the time the expedition departed in March 1993. Little erosion occurred at Oil Barrel Point between 1987/88 and 1992/93, but the sea made inroads immediately west of the barrels. The coast from there to at least the creek outflow near Spit Camp was severely eroded by $1992 / 93$. This was evidenced by the cutting back of the soft, pale sediment cliff to the west of Oil Barrel Point, the exposure of further sealers' artefacts and the continued undercutting of the refuge hut 
at Spit Camp. It was recognised in 1986 that coastal erosion threatened this hut (Kirkwood 1989b); it disappeared after the departure of the 1992 wintering expedition (S. Reeve, pers. comm.).

Photographs taken during the erection of the refuge hut at Spit Bay show the seaward extent of the Stephenson Glacier, which provided a breakwater protecting the shore from the strong southeasterly water movement along the coast. The strength of this longshore drift was demonstrated in 1992 by the movement of a concrete block (consisting of a bag of concrete that became soaked accidentally) $60 \mathrm{~m}$ to the east of the refuge hut. The retreat of this glacier and Brown Glacier is probably the main cause of the accelerated erosion on this coast, while the reduction in sediment input due to the retreat of glaciers is of secondary importance.

\section{Stephenson Lagoon}

Stephenson Lagoon was fresh water with a short, winding stream to the sea on arrival of the 1992 ANARE expedition. Winter storms deepened and straightened the outlet and removed one of the three remaining ridges of moraine debris (remnants of the terminal moraine that made up the spit between lagoon and sea). Breaches in Stephenson Spit sufficient to make crossing difficult were predicted by Kirkwood (1989b) and, by the end of the summer of $1992 / 93$, crossings were prevented by waves breaking into the outlet. Surface-water samples collected from Stephenson Lagoon and from the sea off Spit Bay in March $1993 \mathrm{had}$ salinity values of 17.9 parts per thousand (ppt) and $26.7 \mathrm{ppt}$ respectively. This indicates a considerable mixing of seawater with the lagoon, especially when considering the amount of runoff from the glacier, due to the thaw. The tidal nature of Stephenson Lagoon has had some interesting effects and will lead to further changes.

(1) Marine organisms were common in Compton Lagoon and should become more common in Stephenson Lagoon, should the tidal ingress continue. Amphipods were observed in Stephenson Lagoon after the spit was broached in 1993. (2) The lagoon may not freeze in future, adding to the difficulties of winter foot transport.

(3) Green (1993b) suggested that the tidal nature of Stephenson Lagoon might lead to the more rapid retreat of Stephenson Glacier. This retreat has, in fact occurred, with oblique photographs taken in 1997 (K. Kiernan, pers. comm.) showing a substantial retreat of this glacier, possibly "due to melting by seawater and mechanical fracture following undercutting by tidal ... action" (Allison \& Keage 1986). The land on the eastern side of Stephenson Glacier is very low lying (and may in fact be below sea level beneath the ice). Unless sufficient material is deposited, a channel could be created between Stephenson Lagoon and Glacial Stream. Already by 1992 there was an extensive pro-glacial lake to the immediate east of Stephenson Glacier between these two water bodies.

\section{The northeastern beaches}

The balance on this coast between deposition and erosion has been complex following the retreat of the Compton Glacier, with accumulation in places (such as the spit across Brown Lagoon) and erosion in others (Kirkwood 1989b). There are few fixed points at which erosion rates can be determined along this coast. There appeared to be little erosion on Fairchild Beach, but Skua Beach had changed markedly between 1987/88 and 1992/93. Kirkwood (1989b) had already documented the destruction of sealers' relics, and this continued in 1992. The sea frontage at the tryworks was gradually eaten away in a number of storms in 1992, so that the trypots, inland in 1987, were slowly undermined, with the outermost falling on the beach in December 1992 and disappearing in early 1993. The spit across Brown Lagoon was not broken in 1992/93 and appeared to be one of the more stable sections.

\section{Compton Lagoon}

The satellite image map with coverage of Compton Glacier for 9 September 1988 shows clearly the retreat of the glacier. This was a large ice front on the December 1985 edition of the Natmap HEARD ISLAND 1:50 000 map (based on the 1948 ANARE survey with additional information to 1963) and the changes to $1987 / 88$ were mapped by Kirkwood (1989b). In 1980 the spit had a single breach, which had widened by $1987 / 88$ with the addition of two further breaches (Kirkwood 1989b). The 1992/93 ice front is shown in figure 5 .

\section{CONCLUSION}

The status of the Heard Island coastline was documented in detail up to the summer of $1987 / 88$ by Kirkwood (1989a). Kirkwood's account concluded with speculation, as to further modifications to the Heard Island coastline. These included: (1) Compton Spit disappearing and the lagoon becoming more bay-like;

(2) a reduction in width of Fairchild Beach;

(3) the opening of a breach in Brown Spit;

(4) a reduction in width of Skua Beach;

(5) the opening of a breach in Stephenson Spit resulting in it becoming tidal (as an additional speculation, connection of Stephenson Lagoon with the pro-glacial lake feeding Glacial Stream); and

(6) the loss of Oil-Barrel Point, North Spit Tryworks and the refuge hut at Spit Bay.

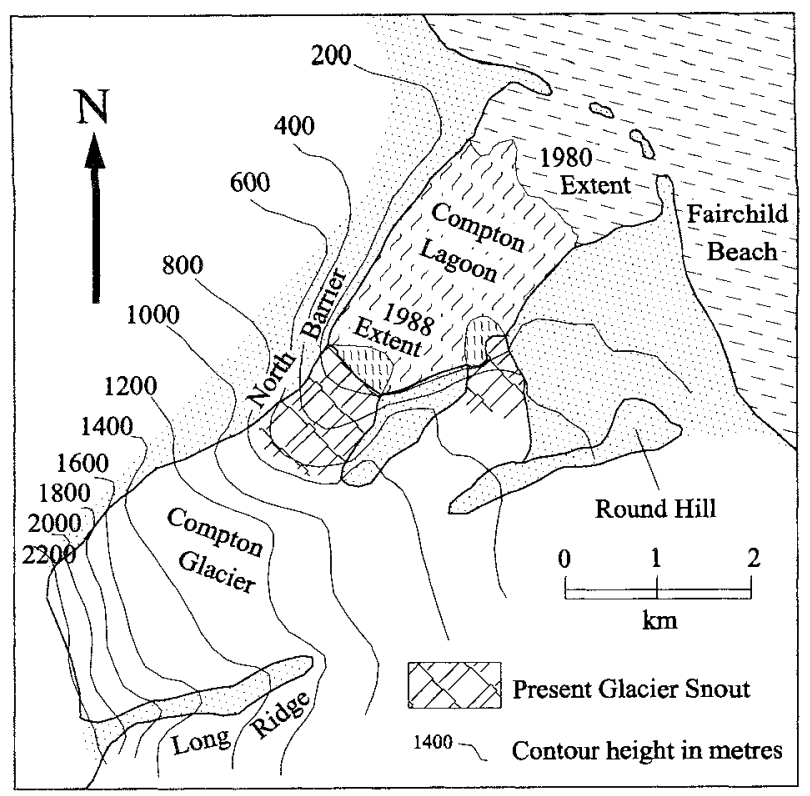

FIG. 5 - Retreat of the Compton Glacier, showing the extent in 1980,1988 and 1993. 
It is a measure of the dynamism of the current erosion regirme on Heard Island that nearly all of these predictions came true within five years of the $1987 / 88$ expedition. This has important ramifications for a number of long-term monitoring or management programmes on the island, not the least of which are the monitoring of penguin and seal numbers (already made difficult by changes in the Spit) and the documentation and conservation of sealers' sites.

Heard Island remains one of our best sites for examining the reality and impacts of climate change but, apart from the period 1947-1954 and 1992/93, there are few climatic data. A remote weather station was erected at Atlas Cove in 1986 but collected data for less than two months. To obtain good quality data, a buoy moored permanently at one of the 1949 locations may be necessary to record sea surface temperature, together with a functioning remote weather station at Atlas Cove. These two would form the basis of a valuable data set. However, they would require a commitment to more regular trips to Heard Island.

\section{ACKNOWLEDGEMENTS}

John Cox drew the figures. Dick Williams provided the sea temperature data from the RSV Aurora Australis. Eric Woehler commented on the manuscript.

\section{REFERENCES}

Allison, I.F. \& KeAGe, P.L., 1986: Recent changes in the glaciers of Heard Island. Polar Rec. 23: 255-271.

BUdD, G.M. \& STEPHENSON, P.J., 1970: Recent glacier retreat on Heard Island. In Gow, A.J. et al. (Eds): PROCEEDINGS OF THE INTERNATIONAL SYMPOSIUM ON ANTARCTIC GLACIOLOGICAL EXPLORATION. Hanover NH 1968: LAHS Publication 86: 449-458.

Bureau of Meteorology,1953: Meteorology: Heard and Macquarie Islands, 1949. ANARE Rep. Ser. D 2: 135 pp

Burton, H.R. \& Williams, D.L., 1985: HEARD ISLAND 1985 REPORT. Australian Antarctic Division, Kingston.

DEACON, G.E.R., 1933: A general account of the hydtology of the South Atlantic Ocean. Discovery Rep. 7: 171 pp.
Ealey, E.H.M. \& Chittleborough, R.G., 1956: Plankton, hydrology and marine fouling at Heard Island. ANARE Interim Rep. 15: 81 pp.

Green, K. (Ed.), 1990: Heard Island 1990 ANARE Report. Unpubl. Antarct. Div. Rep.

Green, K., 1993a: Meteorological observations. In Green, K. (Ed.): Heard Island 1992 ANARE Report. Unpubl. Antarct. Div. Rep.: 181-182.

Green, K., 1993b: Changes in coastal geography. In Green, K (Ed.): Heard Island 1992 ANARE Report. Unpubl. Antarct. Div. Rep.: 177-180.

Howard, A. \& Sverdrup, H.V., 1940: Hydrology. BANZARE Rep. Ser. A 3: 23-126.

JACKA, T.H. \& BUDD, W.F., 1991: Detection of temperature and sea ice extent changes in the Antarctic and Southern Ocean. In Weller, G., Wilson, C.L. \& Severin, B.A.B. (Eds): INTERNATIONAL CONFERENCE ON THE ROLE OF THE POLAR REGIONS IN GLOBAL CHANGE. Vol. 1. University of Alaska, Fairbanks, Alaska: 63-70.

JaCKa, T.H., Christou, L. \& CoOK, B.J., 1984: A data bank of mean monthly and annual surface temperatures for Antarctica, the Southern Ocean and South Pacific Ocean. ANARE Res. Notes 22: $97 \mathrm{pp}$.

KiRKwood, R.J., 1989a: The Heard Island Coastline. In Kirkwood, R.J., Woehler, E.J. \& Burton, H.R. (Eds): Heard Island 1987/88 ANARE Report. Unpubl. Antarct. Div. Rep.: 241-254.

KIRKWOOD, R.J., 1989b:. The state of glaciers at eastern Heard Island: a report on recent retreats. In Kirkwood, R.J., Woehler, E.J. \& Burton, H.R. (Eds): Heard Island 1987/88 ANARE Report. Unpubl. Antarct. Div. Rep.: 265-272.

Ledingham, R. (Ed)., 1987: Heard Island Expedition ANARE 1986-87. Rep. to Aust. Antarct. Div.: 162-164.

Paltridge, G. \& WoOdrufF, S., 1981: Changes in global surface temperature from 1880 to 1977 derived from historical records of sea surface temperature. Mon. Weather Rev. 109: 2427-2434.

WhitField, M. \& JAGNER, D., 1981: MARINE ELECTROCHEMISTRY, A PRACTICAL INTRODUCTION. John Wiley, New York: 529 pp.

(accepted 5 July 1999) 